\title{
Experimental investigation on shear resistance of self-consolidating concrete beams
}

\section{Análise experimental da resistência ao cisalhamento de vigas de concreto autoadensável}

\author{
G. SAVARIS \\ gsavaris@utfpr.edu.br \\ https://orcid.org/0000-0002-3311-2426 \\ R. C. A. PINTO \\ r.pinto@ufsc.br \\ https://orcid.org/0000-0002-0479-080X
}

\begin{abstract}
Self-consolidating concrete stands out for its high fluidity and stability, which are obtained by the reduction of the coarse aggregate dimensions and content in the mixture and also by the addition of superplasticizer and viscosity modifiers. An experimental test program was carried out to evaluate the influence of these particularities of self-consolidating concrete mixtures on the shear capacity of beams with shear reinforcement. Four mixtures of self-compacting concrete and two mixtures of conventionally vibrated concrete with different coarse aggregate size and volume were used for the production of beams to be tested under flexure. The experimental results were compared to those estimated by the ACl-318, CAN A23.3, EC-2 and NBR 6118 design codes. The results demonstrated that the reduction of coarse aggregate dimensions and content in self-compacting concrete mixture did not significantly influence the ultimate shear strength. The shear strengths obtained experimentally were considered adequate to codes estimates, for both concrete types.
\end{abstract}

Keywords: self-consolidating concrete, shear resistance, aggregate interlock, beams.

\section{Resumo}

O concreto autoadensável se destaca pela alta fluidez e estabilidade, sendo estas propriedades obtidas com a redução da granulometria e volume de agregado graúdo da mistura, adição de materiais finos e a utilização de aditivos superplastificantes e modificadores de viscosidade. Um programa experimental foi realizado para avaliar a influência destas particularidades de dosagem do concreto autoadensável na resistência ao cisalhamento de vigas de concreto com armadura transversal. Quatro misturas de concreto auto adensável e duas misturas de concreto convencionalmente vibrado com dimensão máxima e volume de agregado graúdo diferenciados foram utilizados para produção de vigas a serem ensaiadas a flexão com o intuito de comparar os resultados obtidos com os os estimados pelas normas de dimensionamento de estruturas $\mathrm{ACl}$ 318, CAN A23.3, EC-2 e NBR 6118. Os resultados demonstraram que a redução da granulometria e volume de agregado graúdo no concreto autoadensável não influenciaram significativamente na resistência última ao cisalhamento. Entretanto, verificou-se um aumento da parcela de resistência atribuída ao concreto e mecanismos alternativos nas vigas de concreto autoadensável em relação ao concreto convencionalmente vibrado. As resistências ao cisalhamento obtidas experimentalmente foram consideradas adequadas às estimativas das normas, tanto para o concreto convencional quanto para o autoadensável.

Palavras-chave: concreto autoadensável, resistência ao cisalhamento, engrenamento de agregados, vigas. 


\section{Introduction}

In the late 1980s, the reduction of skilled workers and the need to increase the durability of reinforced concrete structures led researchers at the University of Tokyo to develop a high-performance concrete characterized by the ability to spread readily by its own weight, passing by the reinforcement without the necessity of mechanical vibration. This high-performance concrete was called self consolidating concrete (SCC) [1]. The high fluidity is a consequence of the addition of superplasticizers, of the smaller size and reduction of volume fraction of coarse aggregate in the mixture as well as the increase of the volume fraction of fine aggregate. In addition, viscosity and cohesion are ensured by additions of fine materials, such as fly ash, rice husk ash, blast furnace slag, silica fume, and limestone or quartz fillers [2].

These modifications in the mix design together with being a relatively new material, brought about a certain restriction in the use of SCC. There is a need for skilled workers for production and also absence of data regarding the structural performance of this material [3].

According to Domone [4], the tensile and compressive strengths of self consolidating concrete are similar to conventional concrete, however the modulus of elasticity can be up to $40 \%$ lower in self consolidating concrete with compressive strength close to $20 \mathrm{MPa}$, and $5 \%$ lower in high strength concrete, above $90 \mathrm{MPa}$, as compared to conventional concrete. This reduction of the elasticity modulus of self consolidating concrete is caused by the lower volume fraction of coarse aggregates and the increase of the mortar volume fraction. As a consequence, excessive deflections are expected for structures affecting their serviceability limit state [5] [6]. In addition, uncertainties about the shear strength of self consolidating concrete and the lack of specification in the current standards for the design of reinforced concrete structures are still a hindrance for this material to be used by designers in practical applications [3].

Recent studies with conventional concretes have demonstrated that the maximum-size coarse aggregate directly influences aggregate interlock at crack surfaces. Depending on the mixture, the shear strength may be higher for concretes produced with larger aggregates [7] [8]. Since self consolidating concrete requires a smaller content of coarse aggregate with smaller size in its mixture, it may present a reduction on shear strength when compared to conventional concrete [3]. However, this reduction is not a consensus among researchers.
Using direct shear tests, Desnerck et al. [5] verified higher shear strength of self consolidating concrete as compared to conventional concrete. This higher strength was attributed to the improvements in the concrete matrix provided by the use of a greater amount of fine materials, increasing the friction between the surfaces of the cracks, and consequently supplying the reduction of coarse aggregates. On the other hand, Kim et al. [9] verified higher aggregate interlock for conventional concrete in relation to self-consolidating concrete. Shear resistance increased with the increase of the coarse aggregate content in the mixture, regardless of the type of aggregate. Thus, although self consolidating concrete was developed three decades ago, there is no exact definition of its behavior under shear stresses. Therefore, it is necessary to evaluate the influence of self consolidating concrete mixtures with reduced volume fraction of coarse aggregates of smaller sizes on the shear strength of beams with this material. This work intends to contribute to reduce the uncertainties about the structural performance of self consolidating concrete in relation to shear strength, through the formation of a database of experimental tests and comparison with expected values from international standards.

\section{Materials e experimental program}

The experimental program was designed to compare the shear strength of conventional vibrated and self consolidating concretes beams with transverse reinforcement tested under four-point bending tests.

\subsection{Concrete mixtures and casting of beams specimens}

Six concrete mixtures were obtained from a conventional concrete mixture proportion. Two maximum size coarse aggregates and two coarse aggregate volume fractions were used.The mixtures were identified by letters corresponding to concrete type, conventional (CC) or self consolidating (SCC), by the maximum coarse aggregate size, $9.5 \mathrm{~mm} \mathrm{(0)}$ or $19.0 \mathrm{~mm}(1)$, and also by the coarse aggregate volume fraction, normal $(\mathrm{N})$ or reduced by $30 \%(\mathrm{R})$. For concrete mixtures with reduction of coarse aggregate volume fraction, the mixture was complemented with fine aggregate.Furthermore, self-consolidating concretes received addition of limestone filler, in order to increase their viscosity, and superplasticizer admixture based on polycarboxylate, to increase their flowability.

\section{Table 1}

Mixture proportions for CC and CA mixtures $\left(\mathrm{kg} / \mathrm{m}^{3}\right)$

\begin{tabular}{ccccccccc}
\hline Concrete & $\begin{array}{c}\text { Cement } \\
(\mathbf{k g})\end{array}$ & $\begin{array}{c}\text { Filler } \\
(\mathbf{k g})\end{array}$ & $\begin{array}{c}\text { Natural } \\
\text { sand } \\
(\mathbf{k g})\end{array}$ & $\begin{array}{c}\text { Artificial } \\
\mathbf{s a n d} \\
(\mathrm{kg})\end{array}$ & $\begin{array}{c}\text { Coarse } \\
\text { aggregate } \\
\mathbf{0} \\
(\mathrm{kg})\end{array}$ & $\begin{array}{c}\text { Coarse } \\
\text { aggregate } \\
\mathbf{1} \\
(\mathrm{kg})\end{array}$ & $\begin{array}{c}\text { Water } \\
(\mathrm{kg})\end{array}$ & $\begin{array}{c}\text { Superplasticizer } \\
(\mathbf{k g})\end{array}$ \\
\hline CC1 & 385.18 & - & 418.54 & 417.41 & - & 964.59 & 200.29 & - \\
CCO & 385.18 & - & 418.54 & 417.41 & 961.10 & - & 200.29 & - \\
CA1N & 385.18 & 214.77 & 312.88 & 312.04 & - & 964.59 & 200.29 & 0.87 \\
CAON & 385.18 & 214.77 & 312.88 & 312.04 & 961.10 & - & 200.29 & 0.77 \\
CA1R & 385.72 & 215.08 & 456.45 & 455.23 & - & 676.02 & 200.57 & 1.15 \\
CAOR & 385.72 & 215.08 & 456.45 & 455.23 & 673.58 & - & 200.57 & 1.11 \\
\hline
\end{tabular}


Table 2

Fresh and hardened properties of CC and CA mixtures

\begin{tabular}{|c|c|c|c|c|c|c|}
\hline Concrete & $\begin{array}{l}\text { Slump } \\
(\mathrm{mm})\end{array}$ & $\begin{array}{c}\text { Slump flow } \\
(\mathrm{mm})\end{array}$ & $\begin{array}{c}\text { Density } \\
\left(\mathrm{kg} / \mathrm{m}^{3}\right)\end{array}$ & $\begin{array}{c}\begin{array}{l}\text { V-funnel } \\
(\mathrm{s})\end{array} \\
\end{array}$ & $\begin{array}{l}\text { L-box } \\
(\mathrm{mm})\end{array}$ & $\begin{array}{c}f_{c m} \\
(\mathrm{MPa})\end{array}$ \\
\hline $\mathrm{CCl}$ & 90 & - & 2424 & - & - & 47.0 \\
\hline $\mathrm{CCO}$ & 85 & - & 2391 & - & - & 41.2 \\
\hline CAIN & - & 73.5 & 2391 & 19.63 & 0.87 & 48.2 \\
\hline CAON & - & 70.5 & 2391 & 21.52 & 0.81 & 42.7 \\
\hline CAIR & - & 79.5 & 2367 & 11.94 & 0.87 & 47.7 \\
\hline CAOR & - & 78.5 & 2421 & 10.42 & 0.83 & 47.4 \\
\hline
\end{tabular}

Brazilian Portland cement CP V-ARI-RS, similar to ASTM Type $\mathrm{V}$, with high initial strength and sulphate resistant was used.Form removal was performed after 24 hours of casting. The fine aggregate used was a mixtureof $50 \%$ quartz sand, with a fineness modulus of 2.23 and specific mass of $2.67 \mathrm{~kg} / \mathrm{dm}^{3}$, and $50 \%$ granitic rock crushing sand, with fineness modulus of 3.8 and specific mass of $2.68 \mathrm{~kg} / \mathrm{dm}^{3}$. Granite coarse aggregates with maximum sizes of $9.5 \mathrm{~mm}$ and $19.0 \mathrm{~mm}$ and a specific mass of $2.67 \mathrm{~kg} / \mathrm{dm}^{3}$ were used. A calcitic limestone filler, from the metropolitan region of Curitiba-PR, composed mainly of $\mathrm{CaO}$ with $90 \%$ of material passing through the $74 \mu \mathrm{m}$ sieve was also added to the SCC mixes. The mix proportions for the production per $\mathrm{m}^{3}$ of concrete are summarized in Table 1.

All concrete mixes were produced with water cement ratio of 0.52 . Superplasticizer admixture was initially added at $0.3 \%$ of the cement mass, however during concrete production this value was later corrected according to the flowability requirements of each self consolidating concrete mixture. The final values lied between $0.2 \%$ and $0.3 \%$ of the cement mass.

Self consolidating concretes with normal aggregate volume, $\mathrm{CA} 1 \mathrm{~N}$ and $\mathrm{CA} 0 \mathrm{~N}$, were obtained from conventional concrete mixtures, CC1 and CC0, respectively, by replacing $25 \%$ of fine aggregate mass by limestone filler. The same content of filler was used in the self consolidating concretes with reduced aggregate volume, CA1R and CA0R.For these latter mixtures $30 \%$ of the coarse aggregate volume was replaced by fine aggregate thus maintaining the proportion of fine materials around of $600 \mathrm{~kg} / \mathrm{m}^{3}$ of concrete for all self consolidating concrete. CAON, $\mathrm{CA} 1 \mathrm{~N}, \mathrm{CC} 0$ and $\mathrm{CC} 1$ presented $56 \%$ of mortar content whereas for CA1R and CA0R this content increased to $69 \%$ due to the reduction of aggregate volume by $30 \%$ and complementation with small aggregates.

Concrete mixture were evaluated considering its workability according to the slump test, as specified by ABNT NBR NM 67 standard [10], for conventional concrete.For SCC mixtures, their flowability, passing ability and viscosity were evaluated according to the tests defined by ABNT NBR 15823 [11]. The compressive strength of the concrete used to cast the beams specimens was obtained from using cylindrical specimens $(10 \mathrm{~cm}$ in diameter and $20 \mathrm{~cm}$ in height), according to ABNT NBR 5739 [12].The results are presented in Table 2.

Both SCC and CC mixtures were mixed in a $150 \mathrm{~L}$ capacity batch mixer with three beams and three cylindrical specimens cast with each concrete mixture. Formworks made of medium density fiberboard were used for beams specimens where concrete was placed
manually.Conventional concrete beams were vibrated with a $25 \mathrm{~mm}$ diameter immersion vibrator.

After 24 hours of casting, the beams and cylindrical specimens were demolded and stored under plastic canvas. These specimens were moistened daily during the first seven days. They remained under laboratory conditions, with a mean temperature of $22.5^{\circ} \mathrm{C}$ and relative humidity around $75.4 \%$.All experiments were performed at 28 days of age.

\subsection{Details of beams specimens and test set up}

The concrete beams were design to fail by shear when transverse reinforcement yield was reached. The beams had a rectangular cross section of $10 \mathrm{~cm} \times 25 \mathrm{~cm}$, total length of $150 \mathrm{~cm}$, with the distance between the supports of $130 \mathrm{~cm}$. Four point bending tests were performed through load point located at a $50 \mathrm{~cm}$ distance from the supports. The shear span and the effective height of the cross section (a/d) was close to 2.25, according to the scheme shown in Figure 1. All beams were reinforced with two $16 \mathrm{~mm}$ diameter CA-50 reinforcing bars, placed at the bottom of the cross section, corresponding to a longitudinal reinforcement ratio of $1.61 \%$. Two 5 $\mathrm{mm}$ diameter CA-60 reinforcing bars were positioned at the top of the cross-section. The transverse reinforcement consisted of rectangular stirrups spaced $20 \mathrm{~cm}$ along the entire beam, as shown in Figure 2.

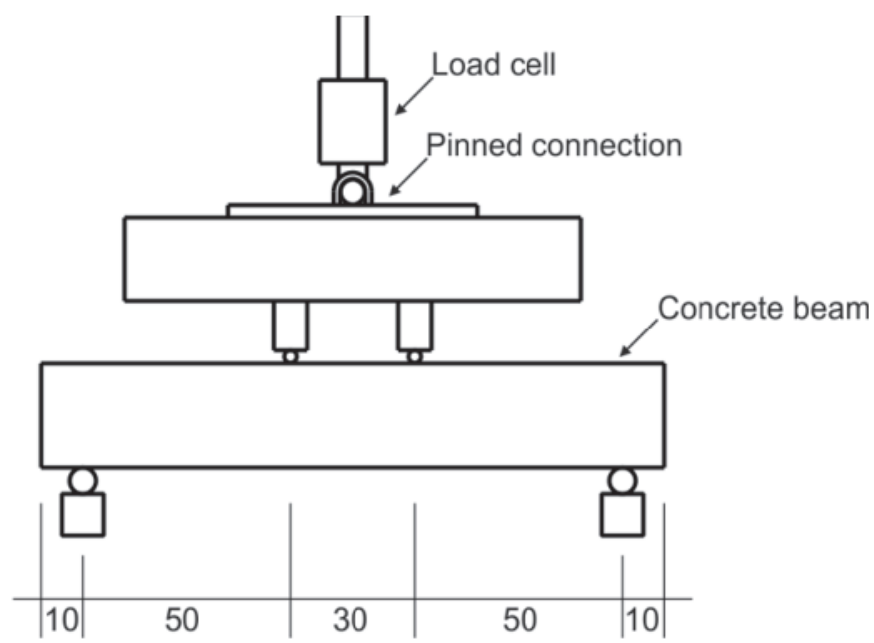

Figure 1

Four-point bending test set-up (dimensions in $\mathrm{cm}$ ) 


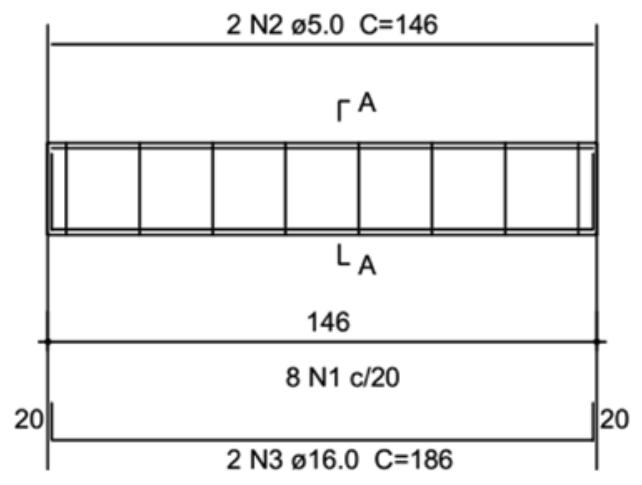

$\underline{\text { SEÇÃO A-A }}$

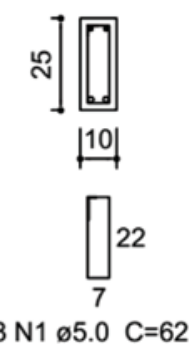

Figure 2

Beam dimension and reinforcement

Loading was applied using a hydraulic jack coupled to a load cell with a capacity of $200 \mathrm{kN}$, at a constant rate of $500 \mathrm{~N} / \mathrm{s}$ until failure. During loading, at loads of $30 \mathrm{kN}, 60 \mathrm{kN}$ and $90 \mathrm{kN}$ the number and position of cracks were identified. These load values were defined from the theoretical load capacity of the beams, aiming to evaluate the behavior of the beams before and after its cracking resistance.

In order to measure the vertical displacement at middle span of the beam, two linear variable displacement transducers (LVDTs) with a measuring capacity of $10 \mathrm{~mm}$ were used.The LVDTs were fixed in aluminum bars installed on the sides of the beams, which were supported on rollers at the ends of the beams. The LVDTs were referenced on steel angles screwed at the neutral axis. Shear crack openings were measured in the two shear spans using LVDTs installed $15 \mathrm{~cm}$ from the load application points, fastened with screws on the upper side of the beam face and in a channel section steel bar screwed on the bottom of the beam. The positions of the LVDTs are shown in Figure 3.

\section{Results and discussion}

\subsection{Cracking pattern and shear resistance}

All beams tested presented a similar behavior regarding cracking. The first flexural crack appeared in the middle of the span, before $30 \mathrm{kN}$ load. The formation of shear cracks happened when the shear force was near to $35 \mathrm{kN}$. The shear crack width at failure was greater than $1.0 \mathrm{~mm}$.

Figures 4 to 6 detailed the observed cracks pattern for all beams at failure. The load, in $\mathrm{kN}$, indicates the corresponding load step while the letter $\mathrm{R}$ represents the cracks that occurred between $90 \mathrm{kN}$ and failure. The dotted lines correspond to the inclination of the shear crack, presented at the upper part of the beam. The inclination of the shear crack presented values between $26.0^{\circ}$ and $54.1^{\circ}$. There was not an observed direct relationship between its inclination and the ultimate shear strength of the beams, as have also occurred in previous tests of beams without transversal reinforcement presented by Savaris and Pinto [13].

During the tests of two beams, CA1N V1 and CA1R V3, there were failures in the mechanism of load application and the data logger. Thus, these samples were discarded. Among the mixtures studied, there was no distinction in the cracking pattern of the beams, with similar cracks between the mixtures and also a great variation in the inclination of the shear crack. Beams CCO V3 and CAON V2 presented failure of the transverse reinforcement at the end of the shear crack, near the longitudinal reinforcement.In these cases, this crack presented inclination greater than $45^{\circ}$ without crossing the transverse reinforcement. Due to this distinct behavior the results obtained for these beams were also disregarded.

Table 3 shows the ultimate shear forces $\left(V_{u}\right)$ resisted by the beams and the mean values for each concrete mix.

Concrete mixtures showed small variation in compressive strength, with values between $41.2 \mathrm{MPa}$ and $48.2 \mathrm{MPa}$, demonstrating that the changes in the mix design had not significant influence on the ultimate shear strength of the beams. The reduction of coarse

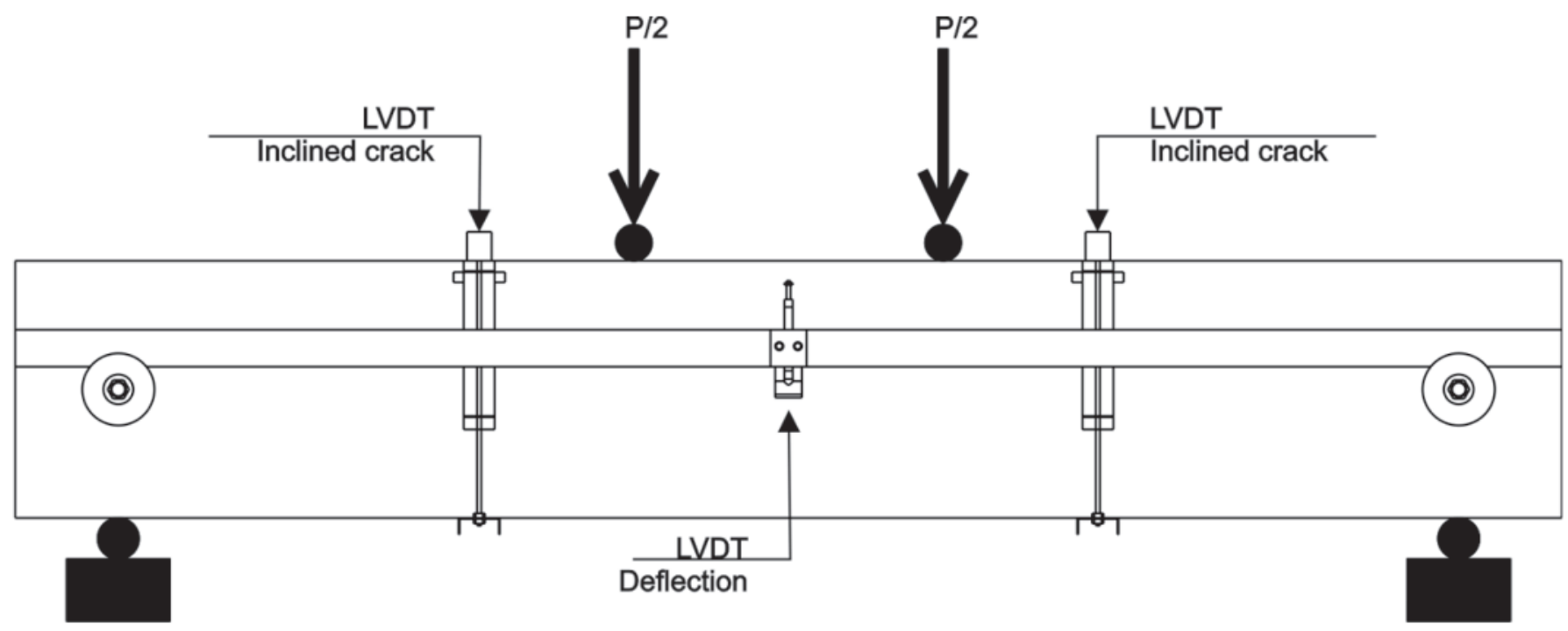

Figure 3

Beam instrumentation 

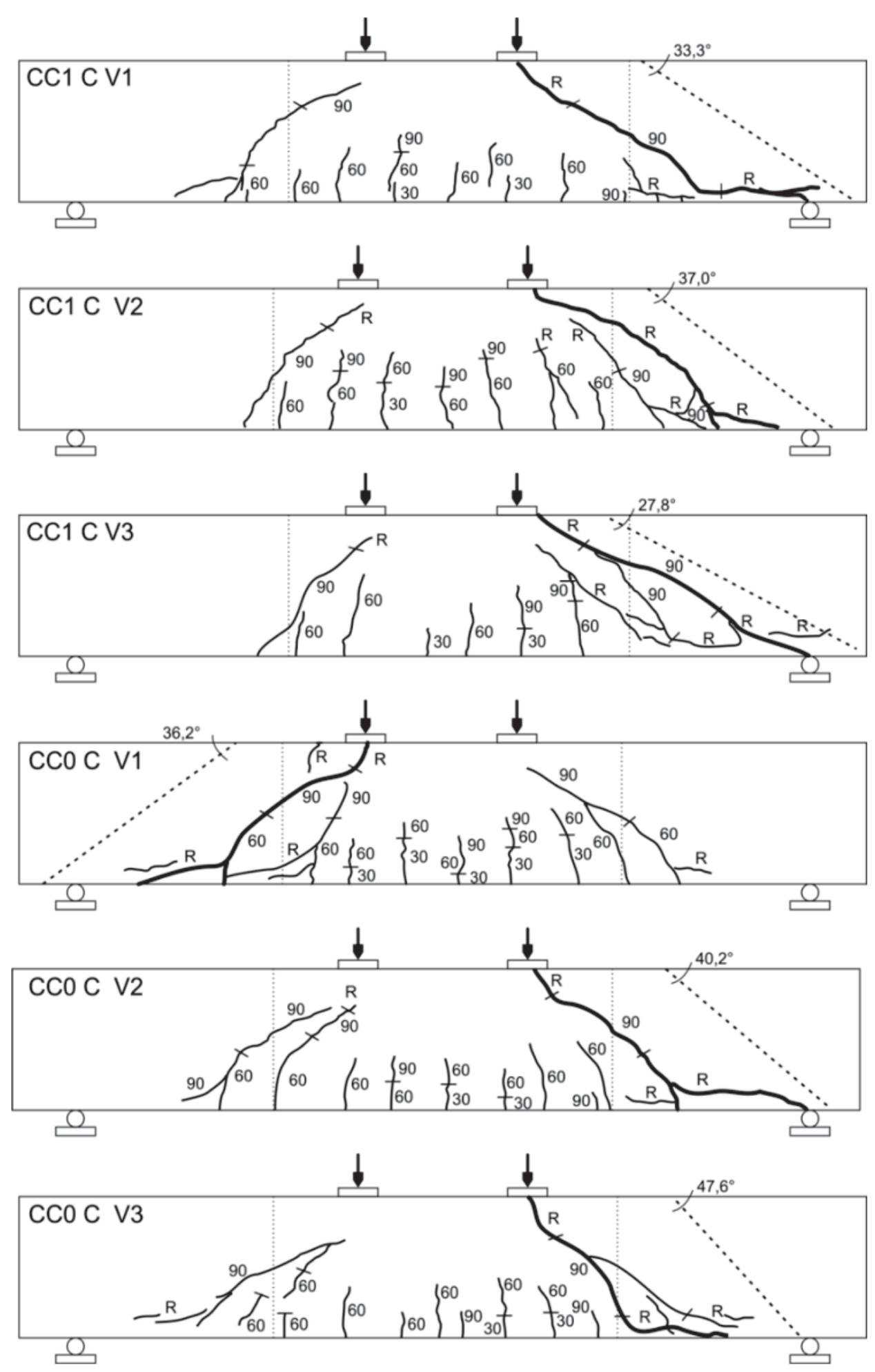

Figure 4

Crack patterns of conventional concrete beams 
aggregate maximum size from $19 \mathrm{~mm}$ to $9.5 \mathrm{~mm}$ showed a greater influence on the shear strength of the conventional concretes, with a reduction of $10.2 \%$, than for self-consolidating concretes, where this variation was smaller than $5 \%$. The reduction of coarse aggregate volume fraction in self consolidating concretes did not show a significant effect on shear strength, with variations smaller than $3 \%$.

\subsection{Transverse reinforcement effect on shear resistance}

In experimental tests of beams without shear reinforcement, Sava- ris and Pinto [13] verified that beams produced with conventional concrete showed higher shear strength than beams made with self consolidating concrete. The reduction of the shear resistance of self consolidating concrete beams was attributed to the higher content of fine materials in their composition and lower aggregate content, thus reducing the aggregate interlock mechanism.

In order to evaluate the effect of the presence of the transverse reinforcement on the shear strength of the beams tested in this work, the results obtained were compared with the results from Savaris and Pinto [13], since these beams presented the same geometric characteristics, longitudinal reinforcement ratio and concrete mix

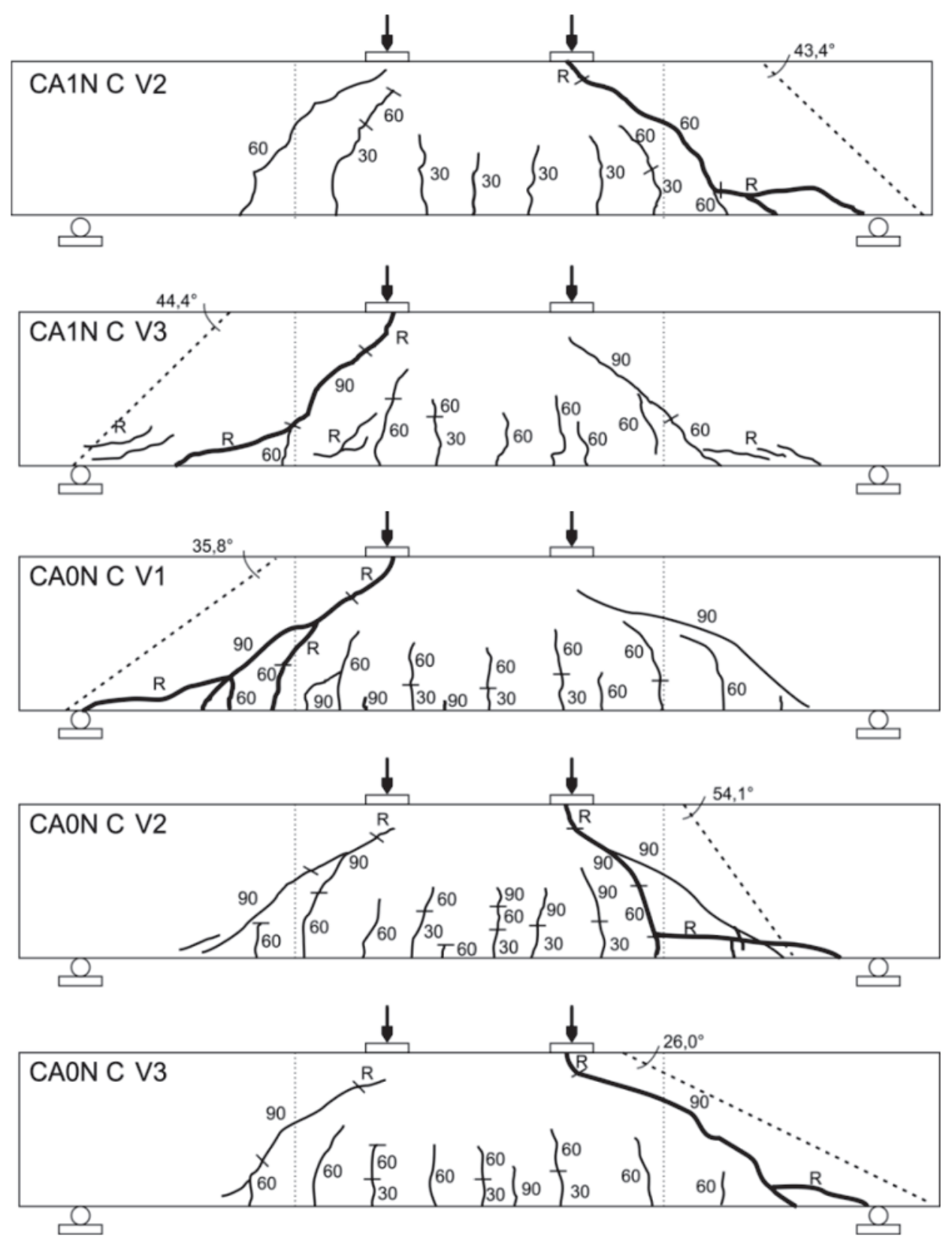

Figure 5

Crack patterns of self consolidating concrete beams with normal amount of coarse aggregate 
proportions. Thus, the shear force resisted by the transverse reinforcement $\left(\mathrm{V}_{\mathrm{sw}}\right)$ was calculated using Equation (1), resulting in $25.64 \mathrm{kN}$. This value was subtracted from the experimental shear force (shown in Table 3), resulting on the shear resistance attributed to concrete and alternative resistance mechanisms $\left(\mathrm{V}_{\mathrm{c}}\right)$.

$V_{s w}=f_{y w} A_{s w}$

where:

$\mathrm{V}_{\mathrm{sw}}$ : shear resistance provided by transverse reinforcement;

$f_{y w}$ : specified yield strength of transverse reinforcement, equal to $658 \mathrm{MPa}$, obtained by tension tests;
$A_{s w}$ : area of shear reinforcement, equal to $38.96 \mathrm{~mm}^{2}$. In order to consider the difference on the compressive strength of the concrete mixes used in the beams with and without transverse reinforcement, the shear resistance $V_{c}$ was normalized, i.e., the value was divided by the square root of the compressive strength of the concrete. Table 4 presents the final normalized shear force resisted by the concrete and alternative resistance mechanisms of the beams with transverse reinforcement $\left(V_{C_{C, n}}\right)$, of the beams without transverse reinforcement $\left(\mathrm{V}_{\mathrm{C}_{-}, \mathrm{n}, \mathrm{n}}\right)$ and the relationship between these values for each concrete mixture.

Table 4 indicates that shear strength values were similar for beams

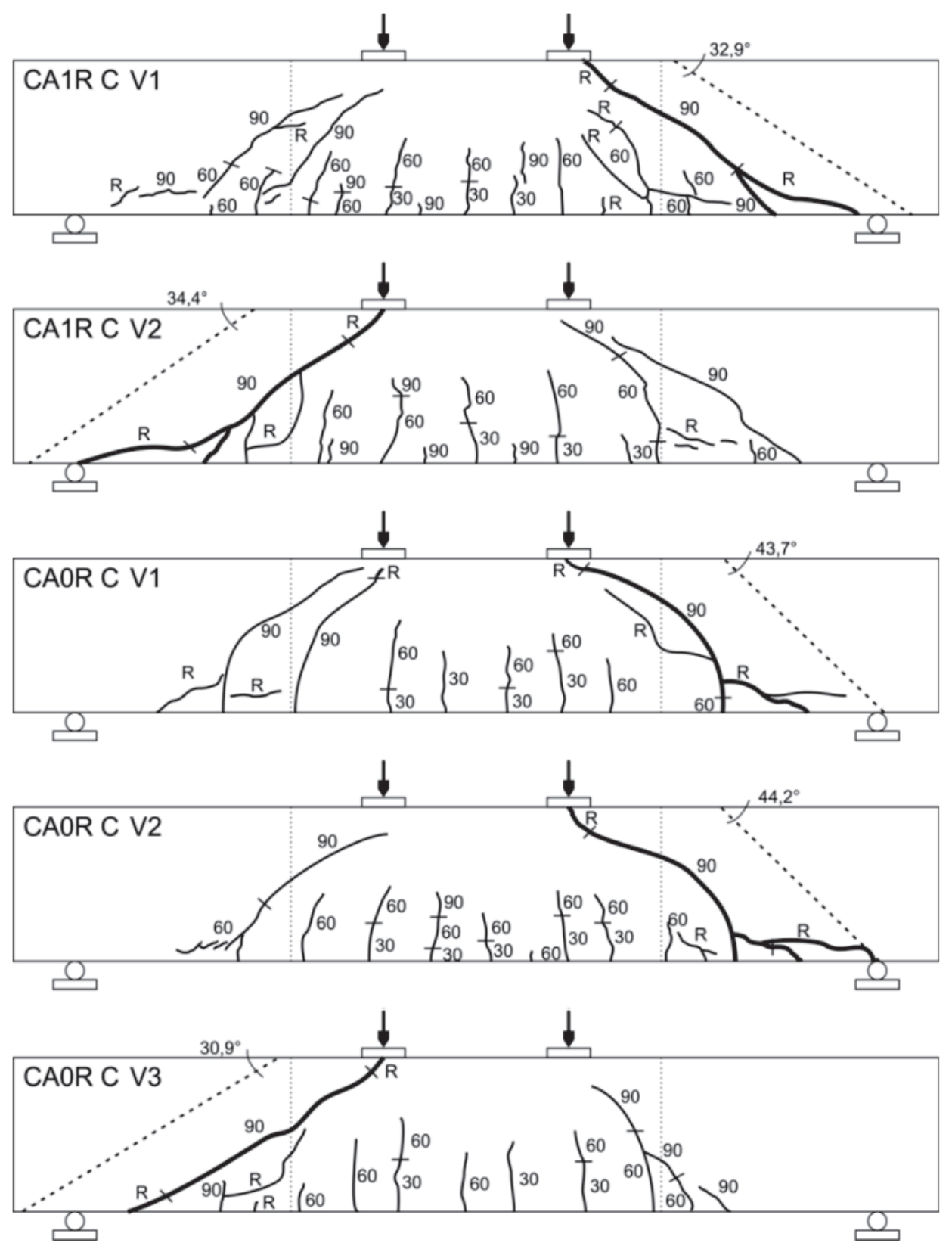

Figure 6

Crack patterns of self consolidating concrete beams with reduced amount of coarse aggregate 
produced with conventional concrete with and without transverse reinforcement. However, the self consolidating concrete beams with transverse reinforcement presented $V_{c_{c}}$ between $22 \%$ and $32 \%$ higher than the strength of the same beams without transverse reinforcement. This increase of the $V_{c}$ was responsible for

\section{Table 3}

Ultimate shear capacity of beams with transverse reinforcement

\begin{tabular}{|c|c|c|c|}
\hline Concrete & $\begin{array}{c}V_{u} \\
(k N)\end{array}$ & $\begin{array}{l}V_{u, m} \\
(k N)\end{array}$ & $\begin{array}{c}\text { Standard } \\
\text { deviation } \\
(\mathrm{kN})\end{array}$ \\
\hline $\mathrm{CCl}-\mathrm{V} 1$ & 72.6 & \multirow{3}{*}{72.6} & \multirow{3}{*}{2.05} \\
\hline $\mathrm{CC} 1-\mathrm{V} 2$ & 70.5 & & \\
\hline $\mathrm{CCl}-\mathrm{V} 3$ & 74.6 & & \\
\hline $\mathrm{CCO}-\mathrm{V} 1$ & 63.6 & \multirow{2}{*}{65.1} & \multirow{2}{*}{2.19} \\
\hline $\mathrm{CCO}-\mathrm{V} 2$ & 66.7 & & \\
\hline $\mathrm{CA} 1 \mathrm{~N}-\mathrm{V} 2$ & 71.8 & \multirow{2}{*}{74.5} & \multirow{2}{*}{3.89} \\
\hline $\mathrm{CA} 1 \mathrm{~N}-\mathrm{V} 3$ & 77.3 & & \\
\hline $\mathrm{CAON}-\mathrm{V} 1$ & 76.5 & \multirow{2}{*}{70.8} & \multirow{2}{*}{8.06} \\
\hline CAON - V3 & 65.1 & & \\
\hline CA1R - V1 & 70.4 & \multirow{2}{*}{72.5} & \multirow{2}{*}{2.90} \\
\hline CA1R - V2 & 74.5 & & \\
\hline CAOR - V1 & 68.5 & \multirow{3}{*}{70.6} & \multirow{3}{*}{3.78} \\
\hline CAOR - V2 & 68.4 & & \\
\hline CAOR - V3 & 75.0 & & \\
\hline
\end{tabular}

reducing the variation of the ultimate strength for beams with transverse reinforcement, supplying the lower resistance observed in self consolidating concrete beams without this reinforcement, as previously presented by Savaris and Pinto [13].

These results can be attributed to the higher bond of the selfreinforcing concrete to the reinforcement, caused by the use of filler, as demonstrated at Almeida Filho et al. [14], Desnerck et al. [5] and Helincks et al. [15], resulting in small shear crack opening and consequently higher aggregate interlock. It should be noted that the beams tested in this work presented a transverse reinforcement ratio close to the minimum required by Brazilian building code, indicating that a greater increase in shear strength can occur in self consolidating concrete beams in relation to the

\section{Table 4}

Normalized shear resistance attributed to concrete of beams with and without transverse reinforcement

\begin{tabular}{|c|c|c|c|}
\hline Concrete & $\begin{array}{c}\mathrm{V}_{\mathrm{C}-\mathrm{C}, \mathrm{n}} \\
\left(\mathrm{kN} . \mathrm{MPa}^{-0.5}\right)\end{array}$ & $\begin{array}{c}\mathrm{V}_{\mathrm{C}_{\mathrm{s}, \mathrm{n}, \mathrm{n}}} \\
\left(\mathrm{kN} \cdot \mathrm{MPq}^{-0.5}\right)\end{array}$ & $\begin{array}{l}\mathrm{V}_{\mathrm{c}_{\mathrm{C}} \mathrm{c}_{\mathrm{n}}} / \mathrm{V}_{\mathrm{c}_{\mathrm{s}, \mathrm{n}, \mathrm{n}}} \\
\left(\mathrm{kN} \cdot \mathrm{KPa}^{-0.5}\right)\end{array}$ \\
\hline $\mathrm{CCl}$ & 6.84 & 6.71 & 1.02 \\
\hline $\mathrm{CCO}$ & 6.15 & 5.95 & 1.04 \\
\hline CA1N & 7.04 & 5.39 & 1.31 \\
\hline CAON & 6.91 & 5.22 & 1.32 \\
\hline CAIR & 6.78 & 5.34 & 1.27 \\
\hline CAOR & 6.53 & 5.37 & 1.22 \\
\hline
\end{tabular}

Table 5

Code based equations to prediction of shear resistance of beams

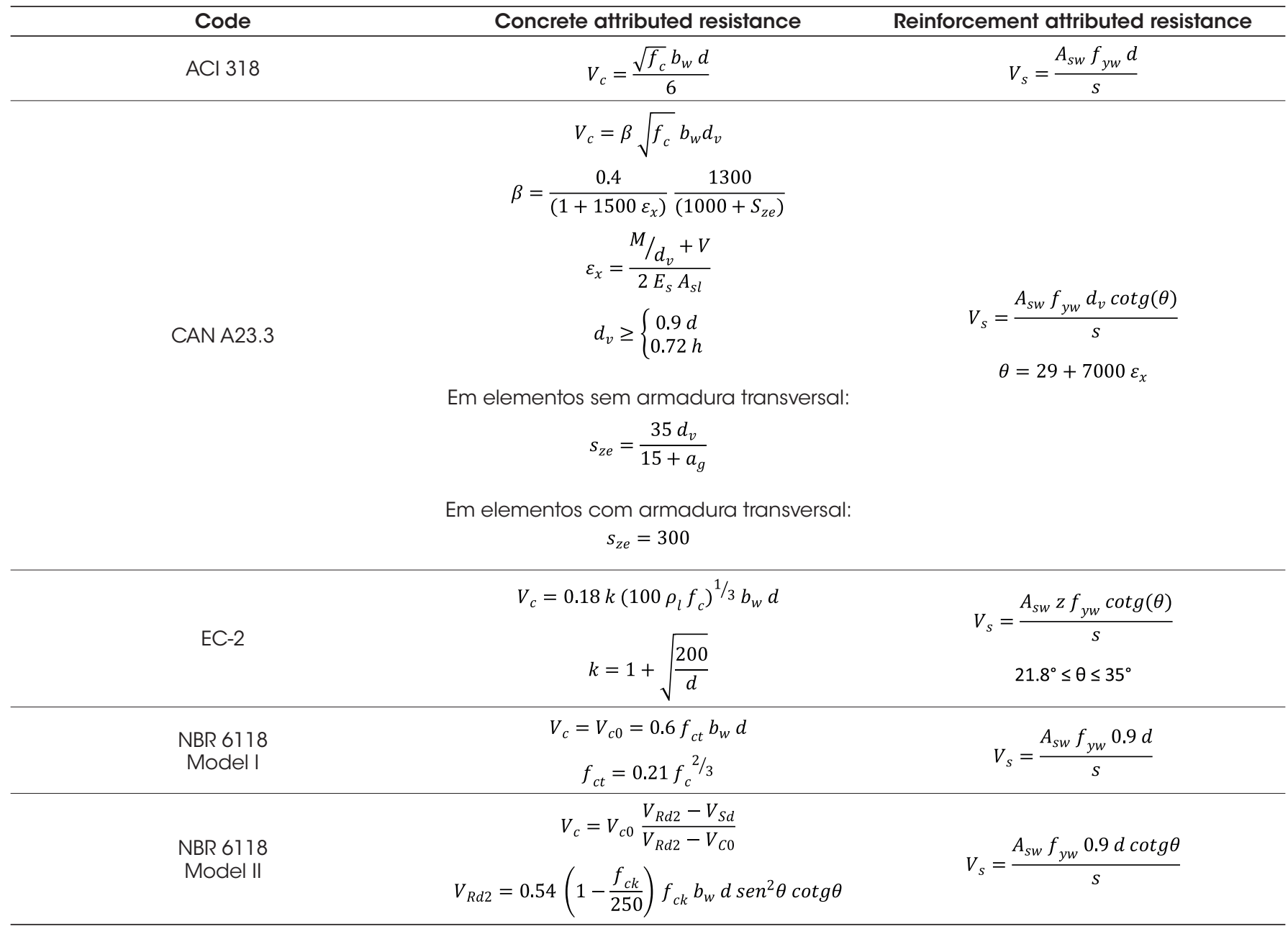


Table 6

Ultimate shear load from experiments, code based prediction and these values ratio

\begin{tabular}{|c|c|c|c|c|c|c|c|c|c|c|c|c|}
\hline \multirow{2}{*}{ Beam } & \multirow{2}{*}{$\begin{array}{l}V_{u, \exp } \\
(\mathrm{kN})\end{array}$} & \multirow{2}{*}{$\begin{array}{l}\mathrm{V}_{\mathrm{u}, \mathrm{exp}, \mathrm{m}} \\
(\mathrm{kN})\end{array}$} & \multicolumn{5}{|c|}{$\begin{array}{l}\text { Code based prediction }-\mathrm{V}_{\mathrm{u} \text {,eo }} \\
(\mathrm{kN})\end{array}$} & \multicolumn{5}{|c|}{ Ratio $V_{u, t e o} / V_{u, \exp }$} \\
\hline & & & $\begin{array}{l}\mathrm{ACl} \\
318\end{array}$ & $\begin{array}{r}\text { CAN } \\
\text { A23.3 } \\
\end{array}$ & EC 2 & $\begin{array}{c}\text { NBR } 6118 \\
\text { MI }\end{array}$ & $\begin{array}{c}\text { NBR } 6118 \\
\text { MII }\end{array}$ & $\begin{array}{l}\mathrm{ACl} \\
318\end{array}$ & $\begin{array}{r}\text { CAN } \\
\text { A23.3 } \\
\end{array}$ & EC 2 & $\begin{array}{c}\text { NBR } 6118 \\
\text { MI }\end{array}$ & $\begin{array}{c}\text { NBR } 6118 \\
\text { MII }\end{array}$ \\
\hline $\mathrm{CCl}-\mathrm{V} 1$ & 72.6 & & & & & & & & & & & \\
\hline $\mathrm{CC} 1-\mathrm{V}_{2}$ & 70.5 & 72.6 & 53.6 & 46.2 & 63.5 & 61.8 & 72.3 & 0.74 & 0.64 & 0.87 & 0.85 & 1.00 \\
\hline $\mathrm{CC} 1-\mathrm{V} 3$ & 74.6 & & & & & & & & & & & \\
\hline $\mathrm{CCO}-\mathrm{V} 1$ & 63.6 & 651 & 510 & 476 & 635 & 588 & 70 & م 8 & 073 & Q 98 & م 0 & 108 \\
\hline $\mathrm{CCO}-\mathrm{V} 2$ & 66.7 & 05.1 & 51.9 & $4 / .0$ & 03.5 & 38.8 & 10.1 & 0.80 & 0.13 & 0.98 & 0.90 & 1.08 \\
\hline $\mathrm{CA} 1 \mathrm{~N}-\mathrm{V} 2$ & 71.8 & 745 & 539 & 458 & 635 & 624 & 726 & 0.72 & 0.61 & 085 & 0.84 & 0.97 \\
\hline CA1N - V3 & 77.3 & 14.0 & 00.7 & 40.0 & 0.0 & 02.4 & 12.0 & 0.12 & & & & \\
\hline CAON - V1 & 76.5 & 70.8 & 52.4 & 46.1 & 63.5 & 59.6 & 69.8 & 0.74 & 0.65 & 0.90 & 0.84 & 0.99 \\
\hline CAON - V3 & 65.1 & & & & & & & 0.14 & 0.00 & 0.70 & & 0.49 \\
\hline CA1R - V1 & 70.4 & 725 & 538 & $\Delta 64$ & 635 & 627 & 728 & 0 74 & $0<4$ & O 88 & 086 & 1 \\
\hline $\mathrm{CA} 1 \mathrm{R}-\mathrm{V} 2$ & 74.5 & $1 / 2.0$ & 53.0 & 40.4 & 03.0 & 02.2 & 12.0 & 0.14 & 0.04 & 0.00 & 0.00 & 1.00 \\
\hline CAOR - V1 & 68.5 & & & & & & & & & & & \\
\hline CAOR - V2 & 68.4 & 70.6 & 53.7 & 46.9 & 63.5 & 62.0 & 73.0 & 0.76 & 0.66 & 0.90 & 0.88 & 1.03 \\
\hline CAOR - V3 & 75.0 & & & & & & & & & & & \\
\hline
\end{tabular}

conventional concrete beams when using higher transverse reinforcement ratio.

\subsection{Comparison of experimental resistance and codes estimates}

The expressions presented by codes to estimate the shear strength of concrete beams when designing structures must result in approximate values to those obtained experimentally. Thus, the safety of buildings is guaranteed with the introduction of resistance factors for materials strength and factored loads

The experimental results obtained for the beams were compared with predictions from ACI 318: 2011 [16], CAN3 A23.3: 2004 [17], EN 1992-1-1: 2004 [18] and ABNT NBR 6118: 2014 [19] codes. The equations presented in Table 5 were used considering resistance factors of 1.0 .

The ultimate shear resistance of beams with transverse reinforcement was calculated by the sum of the portions of concrete and complementary mechanisms $\left(\mathrm{V}_{\mathrm{c}}\right)$ and steel $\left(\mathrm{V}_{\mathrm{sw}}\right)$, except for EN 1992-1-1: 2004 [18] where the concrete and complementary mechanisms contribution are disregarded, assuming that shear force is resisted only by the transverse reinforcement $\left(\mathrm{V}_{\mathrm{sw}}\right)$.

Table 6 depicts the ultimate shear forces obtained experimentally, the predictions calculated by code based equations and also the relation between these values for beams with transverse reinforcement. Inclination of strutof $21.8^{\circ}$ and $30^{\circ}$ were adopted in order to estimate the portion of shear force resisted by the reinforcement in equations from EN 1992-1-1:2004 [18] and Model II of ABNT NBR 6118:2014 [19], respectively, resulting in higher values.

The ratio between the ultimate experimental and estimated shear forces presented values between 0.61 and 1.08. Despite the differences in the flowability, coarse aggregate volume fraction and size, the results did not indicate the influence of these factors in relation to the safety of the code predictions for beam design.

Concrete beams produced with coarse aggregate of smaller size presented lower shear strength and, in the majority of cases, less conservative prediction by the codes equations. However, the variation in the results cannot be considered significant.

In spite of adopting a more refined theoretical model, based on compression fields, which takes into account the longitudinal reinforcement area, the magnitude of the bending moment and the shear force acting, and the spacing between the cracks, the results of CAN3 A23.3: 2004 [17] were conservative in relation to the other codes, with a ratio between prediction and experimental results between 0.61 and 0.73 .

EN 1992-1-1:2004 [18] does not consider the shear force resisted by the concrete, nevertheless this code presented results close to those estimated by the model I of theABNT NBR 6118: 2014 [19], around $90 \%$ of the ultimate shear force obtained experimentally. The values estimated by the Brazilian code presented a better approximation with the experimental results, especially when using the model II with a strut inclination angle of $30^{\circ}$, with ratio between 0.97 and 1.08 .

It should be noted that, although some code predictions have presented values similar or higher than the values obtained experimentally, this does not reflect unsafety of the codes, since the American and Canadian codes consider the specified yield strength of transverse reinforcement limited in $400 \mathrm{MPa}$ while in the European and Brazilian standards this value is $435 \mathrm{MPa}$. The value obtained for yield strength at tensile tests of reinforcement used was $658 \mathrm{MPa}$, so there is a safety margin in the reinforcement resistance around $50 \%$.

Figure 7 shows the predictions of ultimate shear force of the codes as a function of the compressive strength of the concrete, indicating the values corresponding to the ultimate shear force of the tested beams for each concrete mixture. The equations of CAN3 A23.3: 2004 [17] and Model II of NBR 6118: 2014 [19] codes require parameters referring to the acting shear force.thus, values of $\beta$ and $\theta$ were considered for Canadian standard, equal to 0.12 and $40^{\circ}$, respectively obtained by the arithmetic mean of the values 


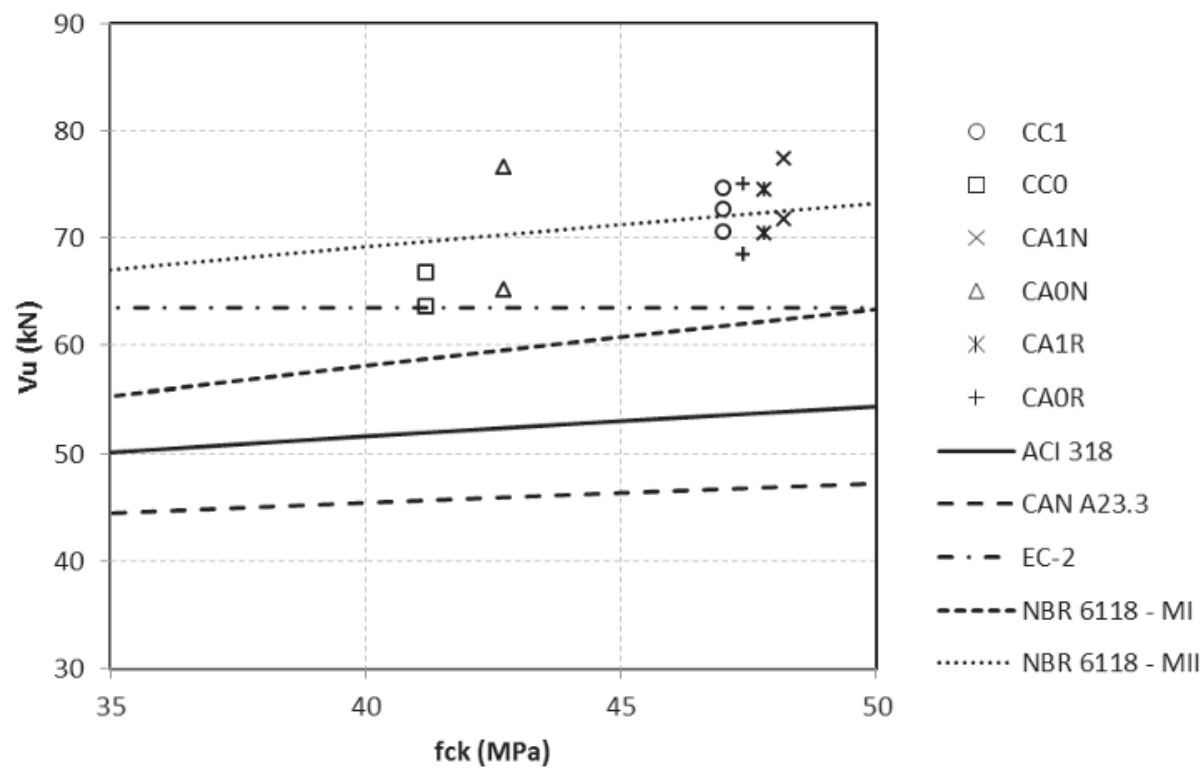

\section{Figure 7}

Code based prediction and experimentally measured of ultimate shear force vs. concrete compressive strength

calculated for the beams tested.For model II of the Brazilian code, which considers a reduction of the portion $\mathrm{V}_{\mathrm{c}}$ when the acting shear force approximates the resistance of the struts of concrete, it was considered that $\mathrm{V}_{\mathrm{c}}$ equals to $77 \%$ of $\mathrm{V}_{\mathrm{c} 0}$.

In relation to $\mathrm{ACl}$ 318: 2011 [16], CAN3 A23.3: 2004 [17], EN 1992-1-1: 2004 [18] and model I of NBR 6118: 2014 [19] codes, it was observed that all the beams tested showed ultimate shear strength higher than the codes predictions. The model II of NBR 6118: 2014 [19] presented a better approximation of the results, with values approximately $8 \%$ higher than the values obtained experimentally. However, this variation does not represent a lack of safety of the model, since this code determines that the yield strength of reinforcement that must be used is equal to $435 \mathrm{MPa}$ as discussed before.

Among the codes, a direct relationship between the ultimate shear force and the compressive strength of concrete was verified, similar to the behavior of the experimental results, except for EN 19921-1:2004 [18], where prediction of shear strength was constant. Its equation considers only the strength of the reinforcement, becoming more conservative as the strength of concrete increases.

\section{Conclusions}

In this work the shear strength of concrete beams with transverse reinforcement was evaluated.The behavior of beams made with conventional and self consolidating concrete was compared.The main goal was to reduce the uncertainties about the structural performance of self consolidating concrete.

The results showed that the reduction of coarse aggregate volume fraction and maximum size, necessary to produce self consolidating concrete, did not result in a significant reduction on the shear strength of SCC concrete beams with transverse reinforcement.
Comparing the strength of beams with transverse reinforcement to the results of beams without this reinforcement, there was an increase on the resistance attributed to the concrete and alternative mechanisms of self consolidating concrete beams in relation to the conventionally vibrated concrete. This increase may be due to an improve on the concrete-reinforcement bond; however, more tests must be performed to assert this statement.

The shear strength estimates, regardless of the safety coefficients of the ABNT NBR 6118: 2014 model II, presented values closer to the results obtained experimentally than the $\mathrm{ACl} 318: 2011$ [16], CAN3 A23.3: 2004 [17], EN 1992-1-1: 2004 [18] and model I of ABNT NBR 6118: 2014 [19], which are considered conservative.All these codes demonstrated to be safe in the design of self consolidating concrete beams.

\section{Acknowledgments}

The authors gratefully acknowledge the Coordination for the Improvement of Higher Education Personnel (CAPES), the Federal University of Santa Catarina and the Federal University of Technology - Paraná for support in the development of this project.

\section{References}

[1] OKAMURA, H.; OZAWA, K.; OUCHI, M. Self consolidating concrete. Structural Concrete, v.1, n 1, p. 3-17, 2000.

[2] BARROS, A. R. Avaliação do Comportamento de Vigas de Concreto Auto-Adensável Reforçado com Fibras de Aço. 2009. 155f.. Dissertação (Mestrado em Engenharia Civil), Universidade Federal de Alagoas, Maceió, 2009.

[3] HASSAN, A. A. A., HOSSAIN, K. M. A., LACHEMI, M. 
Behavior of full-scale self-consolidating concrete beams in shear. Cement \& Concrete Composites, 30 (2008) 588-596.

[4] DOMONE, P. L. A review of the hardened mechanical properties of self consolidating concrete. Cement \& concrete composites, v.29 p. 1-12, 2007.

[5] DESNERCK, P., DE SCHUTTER, G., TAERWE, L. Shear friction of reinforced self consolidating concrete members. ACI Special publication 261-9. American Concrete Institute, Farmington Hills, Michigan. p. 133-141, 2009.

[6] BOEL, V.; DE CORTE, W. Reinforced Self consolidating Concrete Beams Subjected to Static and Dyamic Loads. In: INTERNATIONAL RILEM SYMPOSIUM ON SELF CONSOLIDATING CONCRETE, 6., 2010, Montreal. Proceedings... Montreal: 2010, Vol. II, p. 1173-1182.

[7] SHERWOOD, E. G.; BENTZ, E. C.; COLLINS, M. P. Effect of Aggregate Size on Beam-Shear Strength of Thick Slabs. ACI Structural Journal, Title $n^{\circ} 104-S 19$, p. 180-190, March/April, 2009.

[8] YANG, K. H., SIM, J. I., CHOI, B. J., LEE, E. T. Effect of Aggregate Size on Shear Behavior of Lightweight Concrete Continuous Slender Beams. ACI Materials Journal, V. 108, $N^{\circ}$ 5, Sep.-Oct. 2011, p. 501-509.

[9] KIM, Y. H.; HUESTE, M. B. D.; TREJO, D.; CLINE, D. B. $H$. Shear Characteristics and Design for High-Strength SelfConsolidating Concrete. Journal of Structural Engineering, v. 136, n 8, p. 989 - 1000, August 2010.

[10] ASSOCIAÇÃO BRASILEIRA DE NORMAS TÉCNICAS. NBR NM 67: Concreto - Determinação da consistência pelo abatimento do tronco de cone. Rio de Janeiro, 1998.

[11] ASSOCIAÇÃO BRASILEIRA DE NORMAS TÉCNICAS. NBR 15823: Concreto autoadensável. Rio de Janeiro, 2010.

[12] ASSOCIAÇÃO BRASILEIRA DE NORMAS TÉCNICAS. NBR 5739: Concreto - Ensaio de compressão de corposde-prova cilíndricos. Rio de Janeiro, 2007.

[13] SAVARIS, G., PINTO, R. C. A. Influência do agregado graúdo na resistência ao cisalhamento de vigas de concreto autoadensável. Revista Ibracon de Estruturas e Materiais. Volume 10, Número 1 (Fevereiro 2017) p.30-52.

[14] ALMEIDA FILHO, F. M.; EL DEBS, M. K.; EL DEBS, A. L. $H$. C. Bond-slip behavior of self consolidating concrete and vibrated concrete using pull-out and beam tests. Materials and Structures, v. 41, p. 1073-1089, 2008.

[15] HELINCKS, P., BOEL, V., DE CORTE, W., DE SCHUTTER, G., DESNERCK, P. Structural behaviour of power-type self consolidating concrete: Bond performance and shear capacity. Engineering Structures, V. 48, p. 121-132, 2013.

[16] AMERICAN CONCRETE INSTITUTE. ACI 318: Building code requirements for structural concrete and commentary. Farmington Hills, Michigan, 2011.

[17] CANADIAN STANDARDS ASSOCIATION. A23.3: Design of concrete structures. Ontario, Canada, 2004.

[18] COMITÉ EUROPÉEN DE NORMALISATION. Eurocode 2: Design of concrete structures. Brussels, Belgium, 2004.

[19] ASSOCIAÇÃO BRASILEIRA DE NORMAS TÉCNICAS. NBR 6118: Projeto de Estruturas de Concreto - Procedimentos. Rio de Janeiro, 2014. 